\title{
Integration of Renewable Energy Technologies With Desalination
}

\author{
Ange Abena Mbarga $•$ Lianfa Song $\cdot$ W. Ross Williams • \\ Ken Rainwater
}

Published online: 9 January 2014

(C) Springer International Publishing AG 2014

\begin{abstract}
Remote communities in many countries are in need of dependable and affordable fresh water that must be derived from local brackish water or seawater. Thermal and membrane desalination technologies are available, with significant electrical or thermal energy requirements. Renewable energy from wind, solar, geothermal, or other sources may be necessary when access to grid electricity is limited. This literature review summarizes the research reported in the last three years (mid2010 to mid-2013) by teams of experts in water treatment, renewable energy generation, variable-power system controls, system optimization, and economic analyses.
\end{abstract}

Keywords Desalination · Renewable energy · Wind energy · Solar energy $\cdot$ Photovoltaic $\cdot$ Reverse osmosis $\cdot$ Electrodialysis . Membrane $\cdot$ Hybrid energy $\cdot$ Distillation $\cdot$ Multi-effect distillation · Economic analysis - Seawater · Brackish water . Off-grid · Optimization · Control · Intermittency $\cdot$ Geothermal energy

\section{Abbreviations \\ AD Adsorption desalination \\ BWRO Brackish water reverse osmosis \\ CDP Combined desalination and power \\ CSP Concentrating solar power}

A. A. Mbarga $\cdot$ L. Song $\cdot$ K. Rainwater $(\bowtie)$

Department of Civil and Environmental Engineering, Texas Tech

University, Box 41023, Lubbock, TX 79423, USA

e-mail: ken.rainwater@ttu.edu

A. A. Mbarga

e-mail: ange.abena@ttu.edu

L. Song

e-mail: lianfa.song@ttu.edu

W. Ross Williams

Altresco Companies, 10940 Parker Road, Parker, CO 80134, USA

e-mail: bill.williams@altresco.com

$\begin{array}{ll}\text { DPG } & \text { Diesel power generation or diesel power generator } \\ \text { ED } & \text { Electrodialysis } \\ \text { EDR } & \text { Electrodialysis reversal } \\ \text { ESS } & \text { Energy storage system } \\ \text { ETC } & \text { Evacuated tube thermal collector } \\ \text { FC } & \text { Fixed capacity } \\ \text { FPSC } & \text { Flat-plate solar collector } \\ \text { GC } & \text { Gradual capacity } \\ \text { HOMER } & \text { Hybrid Optimization Model for Electric } \\ & \text { Renewables } \\ \text { MD } & \text { Membrane distillation } \\ \text { MDC } & \text { Microbial desalination cell } \\ \text { MED } & \text { Multi-effect distillation } \\ \text { MEE-FF } & \text { Multi-effect evaporation forward-feed } \\ \text { MSF } & \text { Multi-stage flash } \\ \text { NF } & \text { Nanofiltration } \\ \text { PRO } & \text { Pressure-retarded osmosis } \\ \text { PTC } & \text { Parabolic trough collector } \\ \text { RE } & \text { Renewable energy } \\ \text { RO } & \text { Reverse osmosis } \\ \text { SEC } & \text { Specific energy consumption } \\ \text { SGP } & \text { Salinity gradient power } \\ \text { SWRO } & \text { Seawater reverse osmosis } \\ \text { TDS } & \text { Total dissolved solids } \\ \text { UF } & \text { Ultrafiltration } \\ \text { WEC } & \text { Wave energy converter } \\ \text { WT } & \text { Wind turbine } \\ & \end{array}$

\section{Introduction}

Many communities around the world have limited or no local access to fresh drinking water sources, leading to dependence on BW or SW for potable water supplies. Thermal, such as MSF and MED, and membrane, such as RO and ED, desalination processes can effectively lower the TDS concentrations 
to acceptable levels, but with significant energy requirements. Remote locations in developing countries or small islands may lack access to dependable electrical grid power. Local RE from WTs, PV, CSP, and other sources provides potential alternatives that can either reduce electrical demand from the grid or allow standalone operation. Most RE sources can be intermittent, so the application of RE to produce a target volume of reliable drinking water must address variations in both the water demands and RE supply. During 2010-2013, many researchers published their findings related to conceptual descriptions and designs of potential technology combinations, observations of laboratory, pilot, and full-scale applications, as well as simulations of projected operational and economic conditions. This review provides brief summaries of the major reported findings as well as citations for the interested reader to gather additional details.

Three significant concepts emerge from the recent literature on combinations of RE and desalination, as noted in multiple references.

- Power experts can use "smart grid" concepts to improve $\mathrm{RE}$ and desalination combinations through control systems that adjust for variable RE supply or by considering desalination systems as controllable loads.

- Energy storage systems (ESSs), such as batteries or thermal storage, and planned treated water storage volumes can mitigate the intermittency of wind and solar power sources for continuous water production in standalone applications.

- Hybrid energy combinations of solar, wind, geothermal, and fossil fuel generators can be evaluated for both cost efficiency and freshwater demand satisfaction.

Al-Qaraghuli and Kazmerski [1••] assembled an excellent and succinct overview of the capabilities of conventional thermal and membrane desalination processes and their integration with renewable energy. Their article included comparison of technical aspects, such as process description and energy consumption, and economic aspects, such as estimated cost of water, for various combinations of desalination with RE. In the brief summaries that follow, we have attempted to group the articles based on certain common themes, although there were often multiple overlapping topics shared across their objectives and findings.

\section{Reverse Osmosis Desalination Systems With Various Renewable Energy Sources}

\section{RO Powered by Wind}

Peñate et al. [2•] compared the energy requirements and water production from two hypothetical off-grid SWRO systems.
The first, a FC system, was sized at $1000 \mathrm{~m}^{3} / \mathrm{d}$, while the second, a GC system, included one $200 \mathrm{~m}^{3} / \mathrm{d}$ and two $400 \mathrm{~m}^{3} /$ $\mathrm{d}$ racks that could be turned on as needed. The GC system is able to adapt energy consumption to available WT power. Operational parameters relative to water quality and RO details were simulated with electrical demands of $15-124 \mathrm{~kW}$ for different water production rates. Simulations of RE generation were based on 100,225 , and $300 \mathrm{~kW}$ WTs assisted by a battery ESS and flywheel energy recovery devices. Wind data from the Gran Canaria island in the Spanish archipelago provided the input for the energy generation simulations. Overall, the GC system produced less water than the FC system, with almost $7 \%$ higher SEC in $\mathrm{kWh} / \mathrm{m}^{3}$ of water produced. The GC system had less excess energy production, requiring less energy storage capacity. The authors also recommended consideration of treated water storage capacity as another buffer for system security.

Direct impact of variable electrical supply from WTs on off-grid RO systems has received some attention. Park et al. $[3 \cdot \bullet, 4,5 \cdot \bullet]$ investigated the impact of wind speed fluctuations on the performance of a BWRO system. In the first two studies, a portable small-scale trailer-mounted $300 \mathrm{~L} / \mathrm{hr}$ BWRO system and $1 \mathrm{~kW}$ (at $12.5 \mathrm{~m} / \mathrm{s}$ ) WT were placed in a wind tunnel for controllable wind speed ranges and turbulence fluctuations. Park et al. [3••] observed permeate flux and $\mathrm{NaCl}$ concentration with changing wind speed for 10 min experiments with $30 \mathrm{sec}$ oscillations. The BWRO system performance was unaffected by the wind speed variations from 3.7$10 \mathrm{~m} / \mathrm{s}$. Next, Park et al. [4] investigated the impact of intermittency on the performance of the BWRO system or nopower intervals of $0.5-3 \mathrm{~min}$ in the wind tunnel. Observed permeate TDS concentrations increased most for the shorter $0.5 \mathrm{~min}$ and $1.0 \mathrm{~min}$ no-power intervals, indicating the potential need for ESS or water storage for dilution. Finally, Park et al. [5••] used simulations of their small-scale system to investigate the potential use of supercapacitors to absorb the impacts of both wind speed fluctuations (oscillations of $15 \mathrm{sec}$ to $20 \mathrm{~min}$ ) and intermittency (no-power intervals of 0.5 $5 \mathrm{~min}$ ). Dahioui and Loudiyi [6] simulated a hypothetical wind RO system typical of Morocco and found that reducing maximum capacity of the WT could reduce power fluctuations, as would the use of solenoid valves to manage pressure in the RO system.

Xenarios et al. [7] presented design considerations for selection of a WT for an existing $4500 \mathrm{~m}^{3} / \mathrm{d}$ SWRO plant on the island of Mykonos, Greece. The SWRO plant electrical demand was estimated at $614 \mathrm{~kW}$. Several commercially available WTs were considered, using one year of local wind data, and a 1.5 MW or 1.65 MW WT was sufficient.

Rainwater et al. [8] described a pilot-scale BWRO installation powered by grid-assisted wind energy at Seminole, Texas. An on-site $50 \mathrm{~kW}$ WT provides intermittent electricity for a deep well that taps a brackish aquifer, as well as the 
BWRO system designed to produce $220 \mathrm{~m}^{3} / \mathrm{d}$ (40 gpm) of permeate. The system will be monitored for one year to demonstrate the value of the WT's electrical generation and the production capacity of the deep well.

\section{RO Powered by PV}

Bilton et al. [9] performed theoretical simulations for technical and economic feasibility of PV for remote small-scale off-grid SWRO and BWRO applications. The BWRO sites included New Mexico, Jordan, Australia, and Tunisia. The SWRO locations were Boston, Los Angeles, Cyprus, Jordan, Haiti, and Saudi Arabia. The cost ranges of treated water were 2.17$2.41 \$ / \mathrm{m}^{3}$ and $4.96-7.01 \$ / \mathrm{m}^{3}$ for BWRO and SWRO, respectively. The remote PV/BWRO costs were more than $50 \%$ lower than those with DPG, while the PV/SWRO costs were similar or higher than the DPG equivalent.

Qiblawey et al. [10] described the performance of a small $500 \mathrm{~L} / \mathrm{d}$ BWRO system in northern Jordan powered by PV with battery storage. The system's actual production averaged $267 \mathrm{~L} / \mathrm{d}$ for raw water with $1700 \mathrm{mg} / \mathrm{L}$ TDS, and SEC ranged from $26-31 \mathrm{kWh} / \mathrm{m}^{3}$. Poovanaesvaran et al. [11] presented a conceptual discussion of BWRO with PV supplemented with battery ESS, with a brief review of several installations around the world, as well as comparison of PV and DPG.

Clarke et al. [12, 13••] observed the performance of a small lab-scale BWRO system with a capacity of $15 \mathrm{~L} / \mathrm{hr}$ of permeate, and then used those data in simulation of PV power utilization. SEC increased and permeate flux decreased as the raw water salinity increased from $1 \%$ to $4 \%$. Less permeate water was produced under dynamic conditions with battery ESS, as the battery lost power faster in a dynamic system.

Peterson and Gray [14] reported a small stand-alone PV/ BWRO system at the Brisbane Botanic Gardens in Queensland, Australia. The system had a 30,000 L/d capacity designed for raw groundwater at $1900 \mathrm{mg} / \mathrm{L}$ TDS. Detailed operational data were reported for November 2008 to February 2010. Touati et al. [15] presented a procedure for feasibility design and operational simulation of a standalone RO system powered by PV, a hydrogen-producing electrolyzer powered by excess solar energy, and a fuel cell ESS. They recognized the water problem as an energy problem, leading to this unique proposal that could reduce the required PV area.

\section{RO Powered by RE Combinations}

Spyrou and Anagnostopoulos [16] simulated the energy and economics of a SWRO system for a hypothetical Greek island population of 5,000, with PV $(200 \mathrm{~kW})$ and WTs $(800$ $1500 \mathrm{~kW}$ ) assisted by pumped storage for hydropower generation. Various combinations were evaluated in optimization studies, such as minimizing the cost of produced water, maximizing satisfaction of the variable water demands, impact of population served, and optimal capacity of the pumpedstorage reservoir. Typical projected water costs were $2-4 \$ / \mathrm{m}^{3}$.

Khalifa [17] applied the theoretical HybridRO model to simulate a $50 \mathrm{~m}^{3} / \mathrm{d}$ BWRO system using data for Karbala, Iraq. Electrical supply was provided with a $4 \mathrm{~kW}$ DPG alone, the DPG with WT $(6,30$, and $55 \mathrm{~kW})$, or the DPG with PV (1.9-20 kW). The resulting cost of produced water was $\$ 1.8 /$ $\mathrm{m}^{3}$ for diesel only or DPG with WT and PV, $\$ 2.2 / \mathrm{m}^{3}$ with WT and PV, $\$ 2.3 / \mathrm{m}^{3}$ with PV only, and $\$ 2.4 / \mathrm{m}^{3}$ with WT only.

Karellas et al. [18] analyzed a potential off-grid SWRO system powered by an organic (R134a) Rankine cycle (ORC) turbine driven by solar PTCs. The system was aided by PV and battery ESS to provide electricity to other system components. The system was projected to produce $230 \mathrm{~m}^{3} / \mathrm{d}$ for simulated conditions on the Greek island of Chalki (Halki) at $\$ 13 / \mathrm{m}^{3}$. Peñate and García-Rodríguez [19] considered simple (hexamethyldisiloxane) and two-cycle cascade (hexamethyldisiloxane and isopentane) ORC turbines with a solar PTC heat source for SWRO application in Spain. Their hypothetical system produced $2500 \mathrm{~m}^{3} / \mathrm{d}$ at combined SEC $2.99 \mathrm{kWh} / \mathrm{m}^{3}$. Two different PTC types were also evaluated in detail.

Ben Ali et al. [20] examined a BWRO system in Tunisia powered by both PV and WT, with the advantage that one RE source could be available when the other was not. The control system turned on the BWRO when the available RE was sufficient. Excess energy was dumped, and water storage was used to buffer low-RE periods. Lab-scale experiments provided data for the BWRO, and computer simulations predicted water production under projected RE supply schedules for PV and WTs.

Hossam-Eldin et al. [21] simulated 150 and $300 \mathrm{~m}^{3} / \mathrm{d}$ SWRO systems powered by a hybrid WT/DPG system and a WT/PV/DPG system, respectively, at a site on the coast of Egypt. Both energy systems included battery ESS. The smaller system's optimal cost of energy was $\$ 0.10 / \mathrm{kWh}$, with associated cost of produced water at $\$ 1.79 / \mathrm{m}^{3}$ and excess energy at $33 \%$. The larger system's optimal cost of energy was $\$ 0.11 / \mathrm{kWh}$, and the cost of water was $\$ 1.40 / \mathrm{m}^{3}$, with $30 \%$ excess energy. Under existing conditions, RE from wind was more economical than PV.

Attia [22] proposed a parabolic dish solar collector to convert water to steam and drive a piston device to provide the required pressure to force the raw feed water through a single-stage BWRO or SWRO system. Theoretical analysis indicated potential production rates of $0.055 \mathrm{~m}^{3} / \mathrm{m}^{2} / \mathrm{d}$ and $1.833 \mathrm{~m}^{3} / \mathrm{m}^{2} / \mathrm{d}$ for seawater and brackish water, respectively.

Olwig et al. [23] performed technical and economic analyses of a CSP system to run a $24,000 \mathrm{~m}^{3} / \mathrm{d}$ SWRO facility at Ashdod, Israel, and Aqaba, Jordan. At both sites, the CSP/RO system could produce water for $\$ 2 / \mathrm{m}^{3}$, at best (2.2 and 1.86 times the cost of conventional UF-RO plants at Ashdod and Aqaba, respectively). Similar analyses compared the cost of 
CSP/MED at these two sites. At the Aqaba site, the CSP/MED water would cost $\$ 3.4 / \mathrm{m}^{3}$ (3.6 times the UF-RO price), while the water cost at the Ashdod site would be $\$ 2.6 / \mathrm{m}^{3}$ (2.14 times the UF-RO price). At both sites, RO systems seemed to be superior for the same water production.

Kim et al. [24] provided a theoretical and conceptual review of the application of SGP to drive a PRO system to generate energy for a SWRO process. The brine from a conventional SWRO process can be placed opposite the seawater side of the PRO membrane to produce pressure increases and thus electricity. Unfortunately, appropriate membranes for PRO were not currently commercially available.

In their theoretical investigation of RE and desalination for the Cape Verdean island of Brava, Bognar et al. [25••] simulated conditions for three energy supply scenarios for an existing remote SWRO plant producing $200-600 \mathrm{~m}^{3} / \mathrm{d}$ of permeate. The scenarios considered energy supply from two $600 \mathrm{~kW}$ DPGs and three $275 \mathrm{~kW}$ WTs: (1) for energy only, (2) for constantproduction SWRO, and (3) for variable-production SWRO. The variable-production plant performed best, reducing the overall cost of electricity and the unit cost of water.

Moser et al. [26] compared costs of alternative power supplies for a hypothetical $100,000 \mathrm{~m}^{3} / \mathrm{d}$ desalination system in the Middle East and North Africa (MENA) region. They considered WT, PV, CSP, and a mix of WT/PV/CSP for SWRO, as well as CSP for MED. Battery storage and backup DPGs were combined with WTs and PV, while thermal ESS and backup boilers were associated with CSP. In general, the $\mathrm{RE} / \mathrm{RO}$ systems had lower unit costs of water than the CSP/ MED alternative, and the individual RE sources were less costly than mixed RE.

\section{Other Membrane Desalination Systems With Various RE}

Lopez-Ramirez et al. [27] demonstrated NF desalination in a pilot plant at the Metropolitan Drinking Water Treatment Plant, El Montañés, Puerto Real, Cadiz, Spain. The $50 \mathrm{~m}^{3} / \mathrm{d}$ treatment system was powered by two $3 \mathrm{~kW} \mathrm{WTs,} \mathrm{one} 4.2 \mathrm{~kW}$ PV field, and a battery ESS, while producing $1.1 \mathrm{~L} / \mathrm{hr}$ of permeate at average SEC of $0.60 \mathrm{kWh} / \mathrm{m}^{3}$ during a 64-day demonstration.

Porrazzo et al. [28] observed the behavior of a standalone $150 \mathrm{~L} / \mathrm{d}$ MD system in Italy powered by solar heat collectors. A neural-network multi-input/single-output (MISO) model was developed to project the system's behavior under various solar irradiation conditions. No water cost data were included.

Peñate et al. [29] tested an off-grid EDR system for brackish water desalination powered by PV in Pozo Izquierdo, Spain. The system was powered by two modular PV fields and designed to produce $96 \mathrm{~m}^{3} / \mathrm{d}$. While the feed-water conductivity ranged from 3500 to $5300 \mu \mathrm{S} / \mathrm{cm}$, the product water varied from 114 to $2413 \mu \mathrm{S} / \mathrm{cm}$ for solar irradiation from 600 to $800 \mathrm{~W} / \mathrm{m}^{2}$.
Kim and Logan [30] reviewed the state of the art for MDCs that combine exoelectrogenic bacteria with ED to facilitate seawater desalination. The bacteria congregate at the anode, oxidizing organics and transferring electrons to the anode, thus creating an electrical potential gradient for transport through the ion-exchange membranes. The process is not currently feasible for drinking-water plants.

\section{Thermal Desalination Systems With Various Renewable Energy Sources}

Zhao and Wang [31] observed the performance of convergent/ divergent, orifice, and spray nozzle designs in a lab demonstration of CDP production with a solar pond as the heat source. The convergent/divergent and spray nozzles performed adequately in simultaneous production of energy and potable water. The fresh product water fraction relative to the saline raw water ranged from $4-12 \%$ for input temperatures of $40-90{ }^{\circ} \mathrm{C}$. Ge et al. [32] theoretically modeled a CDP system with a convergent/divergent two-phase nozzle disc integrated into a simple-reaction turbine attached to a generator with a solar pond heat source.

Baharudin et al. [33, 34] considered a PV assembly with battery ESS to power a small lab-scale system for seawater distillation for remote areas such as Kuala Perlis, Malaysia. The experimental results indicated that fresh water was produced, but the water quality analytical method was unclear. The authors performed an economic analysis of the PV distillation system using the HOMER program, but the water production capacity was not specified.

Liu et al. [35] analyzed the thermal and economic performance of a low-temperature parallel-flow MED system for seawater at a hypothetical site in Dalian, China, powered by solar ETCs. The hypothetical system also included a thermal storage tank. The simulations indicated fresh water production at $33 \mathrm{~L} / \mathrm{d} / \mathrm{m}^{2}$ of ETC area, with amortized fresh water cost of approximately $\$ 4.80 / \mathrm{m}^{3}$.

Koroneos and Roumbas [36] contended that geothermal heat sources could be best coupled with MED systems for seawater desalination. They considered the conditions at the Greek island of Nisyros, and performed mathematical simulation and economic analysis for a hypothetical $500 \mathrm{~m}^{3} /$ day plant. Projected treated water costs were less than $\$ 1.4 / \mathrm{m}^{3}$, and environmental impacts were evaluated over the system's life cycle.

Ayhan and Al-Madani [37] proposed combining hybrid wind and solar RE to power natural vacuum desalination of seawater in Bahrain. Solar thermal collectors would provide heat to evaporate seawater under low-pressure conditions, and a WT could power pumps and fans for system operation. The estimated cost of fresh water from a $0.13 \mathrm{~m}^{3} / \mathrm{d}$ system was $\$ 0.70 / \mathrm{m}^{3}$. Gude et al. [38] reported a preliminary field test of a 
two-stage low-temperature/low-pressure distillation process for seawater desalination powered by a FPSC. Experimental and economic results projected that a $500 \mathrm{~L} / \mathrm{d}$ system could generate fresh water at $\$ 7 / \mathrm{m}^{3}$. Gude et al. $[39,40]$ also provided theoretical and economic analyses of a smaller low-temperature desalination that employed FPSCs coupled with thermal energy storage or geothermal energy to allow continuous operation. Their hypothetical system was projected to produce up to $100 \mathrm{~L} / \mathrm{d}$ for solar collector areas up to $18 \mathrm{~m}^{2}$, with $6 \mathrm{~m}^{3}$ of thermal energy storage volume at a $\$ 14 / \mathrm{m}^{3}$ cost of fresh water.

$\mathrm{AD}$ achieves low-temperature thermal distillation using silica gel reactor pairs to facilitate water vapor separation for eventual condensation. $\mathrm{Ng}$ et al. [41•] reported theoretical simulation and lab experiments for AD of seawater in Singapore. AD had higher capital cost coupled with potentially lower electricity cost if RE-provided heat through solar or geothermal sources was more expensive than RO without RE. As was observed in their lab experiments, these costs could be interpreted more positively if the cooling capacity of the AD cycle was also valued. Missimer et al. [42] proposed combining AD with STCs and geothermal energy in alternating 12-hr cycles to maximize desalination capacity in Saudi Arabia.

\section{Evaluation of RE and Desalination Alternatives}

Kavvadias and Khamis [43] reviewed the International Atomic Energy Agency's Desalination Economic Evaluation Program, released as DEEP 3.2, in 2009. This economic model can be used to compare the economics of different membrane or thermal desalination plants powered by nuclear, fossil fuel, and RE. The authors used default model parameters to perform generic comparisons of hypothetical plants and energy sources, and they found that the DEEP code was robust and provided reasonable results. The current DEEP version is DEEP 4.0 (2011, http://www.iaea.org/NuclearPower/Desalination/).

It is challenging to rank the best couplings of RE and desalination systems, and most authors argue for case-bycase assessments. Baharudin et al. [33] devised a multicriteria analysis that considered (1) technical and operational aspects, (2) environmental and land-use impacts, (3) economic cost evaluation, (4) site location characteristics, and (5) energy consumption to compare various $\mathrm{RE} /$ desalination system combinations. Kondili et al. [44•] used the same five criteria to evaluate combinations of RE and desalination for the Greek islands of Agios Efstratios, Anafi, and Kimolos. They evaluated PV-powered RO, WT-powered RO, and geothermal desalination. WT/RO was favored for Agios Efstratios, PV/RO for Anafi, and geothermal for Kimolos.

Kaldellis et al. [45] used the HOMER software system (Lilienthal et al. [46]) to design and simulate an SWRO system powered by a combination of WTs, PV, and biogasfueled internal combustion generator for cogeneration of electricity, heat, and water for the Greek island of Agathonísi. The average water demand was $35 \mathrm{~m}^{3} / \mathrm{d}$, and other energy and heat demands were estimated from observed data. The selected system included three $100 \mathrm{~kW}$ WTs, $200 \mathrm{~kW}$ of PV panels, a $60 \mathrm{~kW}$ biogas generator, and 32 batteries for ESS, all of which easily supplied the SWRO plant.

\section{Energy Load Management With RE and Desalination}

Yoshihara et al. [47] analyzed the interaction between a hypothetical SWRO system and the existing power system at Hateruma-jima, Okinawa Prefecture, Japan. The power system included two $150 \mathrm{~kW}$ DPGs and one $300 \mathrm{~kW}$ DPG, eight $190 \mathrm{~kW}$ flywheel ESSs, and a $275 \mathrm{~kW}$ WT. The challenges were to integrate intermittent wind energy and its attendant power into this electrical grid, and also to consider storage of treated water as part of the temporal simulations. The $20 \mathrm{~kW}$ maximum SWRO plant served as a buffering device for wind energy fluctuations, electricity demand fluctuation, and DPG starting time.

Yılmaz and Söylemez [48] designed and simulated a MEEFF seawater desalination system in Turkey. RE was provided by a FPSC and a small WT. The simulated plant could produce $1000 \mathrm{~L}$ reliably over an average $9 \mathrm{hr} / \mathrm{d}$, which was comparable in performance to a previous pilot-study MED plant in Muscat, Oman.

Malek et al. [49] compared the performance of an ED membrane under both constant and variable voltage to determine the capacity of pulsed voltage to disrupt concentration polarization at the membrane boundary and improve ED performance for brackish $(5 \mathrm{~g} / \mathrm{L} \mathrm{NaCl})$ water treatment. The pulsed regime had a wider safe voltage operating window, and reduced the required desalination time and decreased $\mathrm{pH}$ required at the higher-voltage regime.

Abad et al. [50] performed small-scale experiments to compare the performance of a solar still with pulsating heat pipes and solar thermal collector to that of a basic passive solar still system. Results indicated $75 \%$ improvement in maximum treated water yield over the basic solar still configuration $\left(875 \mathrm{~mL} / \mathrm{m}^{2} / \mathrm{hr}\right.$ vs. $\left.500 \mathrm{~mL} / \mathrm{m}^{2} / \mathrm{hr}\right)$, at an $8 \%$ increase in water $\operatorname{cost}\left(\$ 0.00745 / \mathrm{L} / \mathrm{m}^{2}\right.$ vs. $\left.\$ 0.00690 / \mathrm{L} / \mathrm{m}^{2}\right)$.

\section{Optimization Modeling for Design and Operation of RE and Desalination Systems}

Koutroulis and Kolokotsa [51] assembled an optimization methodology to size SWRO systems powered by PV and/or WTs, both in combination with a battery ESS. Genetic algorithms were used to minimize the total system costs, including 
treated water storage volume, for a 20 -year period for both a 15 -resident community and a single residential household at a site in Crete. In both cases, the combination of wind and PV provided the lowest overall costs.

In Cyprus, Poullikkas [52] also used genetic algorithms to optimize cost of RO-treated water, with $25-100 \%$ of the electricity provided by PV and the balance by the grid, for treatment capacities of $20,000-80,000 \mathrm{~m}^{3} / \mathrm{d}$. Based on the assumed existing conditions, grid-powered RO had the lowest water cost per unit volume.

Barrufet and Mareth [53] used the HOMER software to simulate standalone BWRO powered by combinations of PV, WTs, DPG, and battery storage for freshwater production in the oil fields of West Texas. They considered a hypothetical $23 \mathrm{~m}^{3} /$ d system treating feed water at $10,000 \mathrm{mg} / \mathrm{L}$ TDS for interest rates of $4-6 \%$ and project lifetimes of 5-20 years. The ranges of optimal power provided by the PV panels, WTs, and DPG were $0-2,2-4,6.4-12.8$, and $6-7 \mathrm{~kW}$, respectively. If single power sources were used, the optimal power source was $8 \mathrm{~kW}$ by DPG, followed by $15 \mathrm{~kW}$ by WTs, and $25 \mathrm{~kW}$ by PV panels.

Cherif and Belhadj [54] simulated a hypothetical hybrid BWRO system powered by a $10 \mathrm{~kW}$ WT and $400 \mathrm{~m}^{2}$ of PV panels in the southern Djerba Tunisian island. The raw water TDS was $5400 \mathrm{mg} / \mathrm{L}$, and the BWRO system performance was simulated with the ROSA software package. Estimated permeate production ranged from 57 to $111 \mathrm{~m}^{3} / \mathrm{d}$, but no cost of water was provided.

Chaaben et al. [55] simulated a small BWRO system powered by $\mathrm{PV}$ with battery storage as a multi-input/multioutput (MIMO) process. Their model was intended for process control to optimize operating conditions and reduce water cost for small standalone systems in Tunisia.

Bourouni et al. [56] and M'Barek et al. [57] developed an optimal design model based on genetic algorithms to compare alternative combinations of small RO systems with WT, PV, and battery power for sites in Tunisia. The optimization minimized the total net present cost of the system, including capital, operation, maintenance, and replacement costs. The model was demonstrated for the conditions of the village of Ksar Ghilène, with 300 residents and water demand of $15 \mathrm{~m}^{3} /$ d. The optimal solution of $11 \mathrm{~kW} \mathrm{PV/RO} \mathrm{with} 200$ Ah battery storage at $\$ 2.62 / \mathrm{m}^{3}$ of produced water differed from the existing $10 \mathrm{~kW} \mathrm{PV/RO} \mathrm{with} 600$ Ah battery storage at $\$ 3.56 / \mathrm{m}^{3}$. The optimal solution result also compared well with the numerical result of the HOMER software.

Mousa et al. [58] developed a numerical optimization model for design of hybrid WT and PV RE to drive BWRO in Abu Dhabi. Capital and operating costs were considered for a hypothetical community of 100 people for a 20 -year project life. For estimated SEC of $2.5,5$, and $7.5 \mathrm{kWh} / \mathrm{m}^{3}$, the respective costs for produced water were $0.50,0.85$, and $1.21 \$ / \mathrm{m}^{3}$.

Palacin et al. [59] employed a hybrid predictive control algorithm to optimize the operation of a standalone $\mathrm{RO}$ plant powered by wind and solar RE, supplemented by a diesel generator. Their hypothetical simulations included sizing of treated water storage tanks and membrane maintenance to prevent fouling, while trying to meet variable water demand.

\section{Conclusions}

Researchers around the world continue to look for ways to provide fresh drinking water in remote locations that must rely on brackish water or seawater supplies. The reviewed articles demonstrate concern for a wide spectrum of treatment capacities, from individual residences to communities of several thousand people, most often in standalone off-grid locations. Experiments and simulations demonstrated that the variability and intermittency of wind and solar RE as power sources for desalination can be addressed through ESSs, proper sizing of treatment capacity and water storage, and hybrid combinations with fossil fuel generators or grid access. Optimal combinations of energy supply and treatment systems are likely to vary from region to region with variations in local raw water qualities, RE sources, and access and cost of grid energy. In light of the variety and novelty of these RE and desalination combinations, more effort should be devoted to clarifying their cost structure so that decision-makers (either individuals or municipalities) can confidently select the best technologies for implementation. We hope that this summary of the state of the art for RE-powered desalination will provide incentives for the advanced water treatment and RE equipment manufacturers to recognize the market potential for appropriately sized systems for these remote applications.

\section{Compliance with Ethics Guidelines}

Conflict of Interest Ange Abena Mbarga, Lianfa Song, W. Ross Williams, and Ken Rainwater declare no conflicts of interest.

Human and Animal Rights and Informed Consent This article does not contain any studies with human or animal subjects performed by any of the authors.

\section{References}

Papers of particular interest, published recently, have been highligted as:

- Of importance

•• Of major importance

1.• Al-Qaraghuli A, Kazmerski LL. Comparison of Technical and Economic Performance of the main Desalination Processes with and without Renewable Energy Coupling. Proceedings of the American Solar Energy Society World Renewable Energy Forum. 2012;1-8. This paper provides a clear overall view of various systems in terms of requirements, such as energy consumption, and performance, such as cost of treated water. 
2. Peñate B, Castellano F, Bello A, García-Rodríguez L. Assessment of a stand-alone gradual capacity reverse osmosis desalination plant to adapt to wind power availability: a case study. Energy. 2011;36(7):4372-84. This paper clearly explains the challenges of synchronizing desalination with wind availability..

3.• Park GL, Schäfer AI, Richards BS. Renewable energy powered membrane technology: the effect of wind speed fluctuations on the performance of a wind-powered membrane system for brackish water desalination. J Membr Sci. 2011;370(1-2):34-44. This paper provides great detail about the impact of intermittence on the desalination process..

4. Park GL, Richards BS, Schäfer AI. The effect of intermittent operation on a wind-powered membrane system for brackish water desalination. Water Sci Technol. 2012;65(5):867-74.

5.• Park GL, Schäfer AI, Richards BS. Renewable energy-powered membrane technology: supercapacitors for buffering resource fluctuations in a wind-powered membrane system for brackish water desalination. Renew Energy. 2013;50:126-35. This paper makes a very good case for the use of supercapacitors to mitigate intermittence.

6. Dahioui Y, Loudiyi K. Wind Powered Desalination. Proceedings of 2013 International Renewable and Sustainable Energy Conference, IRSEC 2013. 2013:257-62.

7. Xenarios G, Papadopoulos P, Tzen E. Wind desalination for the Island of Mykonos in Greece: a case study. Desalin Water Treat. 2013;51(4-6):1219-28.

8. Rainwater K, Nash P, Song L, Schroeder J. The Seminole project: renewable energy for municipal water desalination. J Contemp Water Res Educ. 2013;151:50-60.

9. Bilton AM, Wiesman R, Arif AFM, Zubair SM, Dubowsky S. On the feasibility of community-scale photovoltaic-powered reverse osmosis desalination systems for remote locations. Renew Energy. 2011;36(12):3246-56.

10. Qiblawey H, Banat F, Al-Nasser Q. Performance of reverse osmosis pilot plant powered by Photovoltaic in Jordan. Renew Energy. 2011;36(12):3452-60.

11. Poovanaesvaran P, Alghoul MA, Sopian K, Amin N, Fadhel MI, Yahya M. Design aspects of small-scale photovoltaic brackish water reverse osmosis (PV-BWRO) system. Desalin Water Treat. 2011;27(1-3):210-23.

12. Clarke D, Al-Abdeli Y, Kothapalli G. Modelling Small-Scale Stand-Alone (PV) Energy Systems with Reverse Osmosis Integration. 19th International Congress on Modelling and, Simulation. 2011;1-7.

13.• Clarke D, Al-Abdeli YM, Kothapalli G. The effects of including intricacies in the modelling of a small-scale solar-PV reverse osmosis desalination system. Desalination. 2013;311:127-36. This detailed analysis describes application of a battery storage system to deal with intermittence arising from the integration of renewables and an RO system..

14. Peterson EL, Gray SR. Effectiveness of desalination powered by a tracking solar array to treat saline bore water. Desalination. 2012;293:94-103.

15. Touati S, Belkaid A, Benabid R, Halbaoui K, Chelali M. Prefeasibility design and simulation of hybrid PV/fuel cell energy system for application to desalination plants loads. Procedia Eng. 2012;33:366-76

16. Spyrou ID, Anagnostopoulos JS. Design study of a stand-alone desalination system powered by renewable energy sources and a pumped storage unit. Desalination. 2010;257(1-3):137-49.

17. Khalifa AJN. Evaluation of different hybrid power scenarios to Reverse Osmosis (RO) desalination units in isolated areas in Iraq. Energy Sustain Dev. 2011;15(1):49-54.

18. Karellas S, Terzis K, Manolakos D. Investigation of an autonomous hybrid solar thermal ORC-PV RO desalination system. The Chalki island case. Renew Energy. 2011;36(2):583-90.
19. Peñate B, García-Rodríguez L. Seawater reverse osmosis desalination driven by a solar organic rankine cycle: design and technology assessment for medium capacity range. Desalination. 2012;284:8691.

20. Ben Ali I, Turki M, Belhadj J, Roboam X, Energy Management of a Reverse Osmosis Desalination Process Powered by Renewable Energy Sources. 16th IEEE Mediterranean Electrotechnical Conference (MELECON), 2012. 2012:800-5.

21. Hossam-Eldin A, El-Nashar AM, Ismaiel A. Investigation into economical desalination using optimized hybrid renewable energy system. Electr Power Energy Syst. 2012;43(1):1391-400.

22. Attia A. Thermal analysis for system uses solar energy as a pressure source for reverse osmosis (RO) water desalination. Sol Energy. 2012;86(9):2486-93.

23. Olwig R, Hirsch T, Sattler C, Glade H, Schmeken L, Will S, et al. Techno-economic analysis of combined concentrating solar power and desalination plant configurations in Israel and Jordan. Desalin Water Treat. 2012;41(1-3):9-25.

24. Kim J, Lee J, Kim JH. Overview of pressure-retarded osmosis (PRO) process and hybrid application to sea water reverse osmosis process. Desalin Water Treat. 2012;43(1-3):193-200

25.• Bognar K, Pohl R, Behrendt F. Seawater reverse osmosis (SWRO) as deferrable load in microgrids. Desalin Water Treat. 2013;51(4 6):1190-9. This makes the case for efficient use of power (reducing dump loads, and storage capacity needed) with clear economic analyses and detailed results.

26. Moser M, Trieb F, Fichter T, Kern J. Renewable desalination: a methodology for cost comparison. Desalin Water Treat. 2013;51(4 6):1171-89.

27. López-Ramírez JA, Acevedo A, Castañeda RJ, García-Vaquero Marín N. Sustainable improvement of drinking water quality by nanofiltration powered by renewable energy. Water Sci Technol Water Supply. 2013;13(2):309-18.

28. Porrazzo R, Cipollina A, Galluzzo M, Micale G. A neural networkbased optimizing control system for a seawater-desalination solarpowered membrane distillation unit. Comput Chem Eng. 2013;54: 79-96.

29. Peñate B, Círez F, Domínguez FJ. Design and testing of an isolated commercial EDR plant driven by solar photovoltaic energy. Desalin Water Treat. 2013;51(4-6):1254-64.

30. Kim Y, Logan BE. Microbial desalination cells for energy production and desalination. Desalination. 2013;308:122-30.

31. Zhao Y, Wang H. Experimental study on the influence of the nozzle on combined desalination and power generation system. Asia Pac Power Energy Eng Conf. 2010;2010:1-4.

32. Ge X, Liu R, Jiao Z, Zhao Y. The Study on Combined Desalination and Power Generation System using Solar Pond. 2011 International Conference on Materials for Renewable Energy \& Environment. 2011; 1:119-23.

33. Baharudin NH, Mansur TMNT, Ali RB, Yatim Y, Wahab AAA. Optimization Design and Economic Analysis of Solar Power System with Sea Water Desalination for Remote Areas. 2011 I.E. Colloquium on Humanities, Science and Engineering Research. 2011:335-9.

34. Baharudin NH, Mansur TMNT, Ali RB, Wahab AAA, Rahman NA, Ariff EARE, Ali A. Mini-Grid Power system Optimization Design and Economic Analysis of Solar Powered Sea Water Desalination Plant for Rural Communities and Emergency Relief Conditions. 2012 I.E. International Power Engineering and Optimization Conference. 2012:465-9.

35. Liu X, Chen W, Shen S, Gu M, Cao G. The research on thermal and economic performance of solar desalination system with evacuated tube collectors. 2013;51(19-21):3728-37.

36. Koroneos C, Roumbas G. Geothermal waters heat integration for the desalination of sea water. Desalin Water Treat. 2012;37(1-3): 69-76. 
37. Ayhan T, Madani HA. Feasibility study of renewable energy powered seawater desalination technology using natural vacuum technique. Renew Energy. 2010;35(2):506-14.

38. Gude VG, Nirmalakhandan N, Deng S, Maganti A. Feasibility study of a new two-stage low temperature desalination process. Energy Convers Manag. 2012;56:192-8.

39. Gude VG, Nirmalakhandan N, Deng S, Maganti A. Low temperature desalination using solar collectors augmented by thermal energy storage. Appl Energy. 2012;91(1):466-74.

40. Gude VG, Nirmalakhandan N, Deng S. Sustainable low temperature desalination: a case for renewable energy. J Renew Sust Energ. 2011;3:1-25.

41. Ng KC, Thu K, Kim Y, Chakraborty A, Amy G. Adsorption desalination: an emerging low-cost thermal desalination method. Desalination. 2013;308:161-79. This paper is remarkable because it posits adsorption desalination as a technology that may rival reverse osmosis in the future.

42. Missimer TM, Kim YD, Rachman R, Ng KC. Sustainable renewable energy seawater desalination using combined-cycle solar and geothermal heat sources. Desalin Water Treat. 2013;51(4-6):1161-70.

43. Kavvadias KC, Khamis I. The IAEA DEEP desalination economic model: a critical review. Desalination. 2010;257(1-3):150-7.

44. Kondili E, Kaldellis JK, Paidousi M. A multicriteria analysis for the optimal desalination-RES system. Spec Focus Small Greek Islands. 2012;51(4-6):1205-18. Different desalination systems coupled with renewable energy technologies can be very difficult to compare. This paper provides a framework for those comparisons..

45. Kaldellis JK, Gkikaki A, Kaldelli EI, Kapsali M. Investigating the energy autonomy of very small non-interconnected islands. A case study: Agathonisi, Greece. Energy Sustain Dev. 2012;16(4):47685.

46. Lilienthal P, Lambert P, and Lambert T. Getting Started Guide for HOMER Legacy (Version 2.68). National Renewable Energy Laboratory. 2011:1-28.

47. Yoshihara T, Yokoyama A, Imanaka M, Onda Y, Baba J, Kuniba Y, et al. A new method for securing regulating capacity for load frequency control using seawater desalination plant in Small Island Power System. Int Conf Power Syst Technol. 2010;2010:1-6.
48. Y1lmaz IH, Söylemez MS. Design and computer simulation on multieffect evaporation seawater desalination system using hybrid renewable energy sources in Turkey. Desalination. 2012;291:23-40.

49. Malek P, Ortiz JM, Richards BS, Schäfer AI. Electrodialitic removal of $\mathrm{NaCl}$ from water: impacts of using pulsed electric potential on ion transport and water dissociation phenomena. J Membr Sci. 2013;435:99-109.

50. Abad HKS, Ghiasi M, Mamouri SJ, Shafii MB. A novel integrated solar desalination system with a pulsating heat pipe. Desalination. 2013;311:206-10.

51. Koutroulis E, Kolokotsa D. Design optimization of desalination systems power-supplied by PV and $\mathrm{W} / \mathrm{G}$ energy sources. Desalination. 2010;258(1-3):171-81.

52. Poullikkas A. An Optimization model for the production of desalinated water using photovoltaic systems. Desalination. 2010;258(13):100-5.

53. Barrufet MA, Mareth BC. Evaluation of renewable energy as a source of power for desalination of remote-oilfield brines. SPE Proj Facil Constr. 2010;5(2):97-103.

54. Cherif H, Belhadj J. Large-scale time evaluation for energy estimation of stand-alone hybrid photovoltaic-wind system feeding a reverse osmosis desalination unit. Energy. 2011;36(10):6058-67.

55. Chaaben AB, Andoulsi R, Sellami A, Mhiri R. MIMO modeling approach for a small photovoltaic reverse osmosis desalination system. J Appl Fluid Mech. 2011;4(1):35-41.

56. Bourouni K, M'Barek TB, Taee AA. Design and optimization of desalination reverse osmosis plants driven by renewable energies using genetic algorithms. Renew Energy. 2011;36(3):936-50.

57. M'Barek TB, Bourouni K, Ben Mohamed KB. Optimization coupling RO desalination unit to renewable energy by genetic algorithms. 2012;51(7-9):1416-28.

58. Mousa K, Diabat A, Fath H. Optimal design of a hybrid solar-wind power to drive a small-size reverse osmosis desalination plant. Desalin Water Treat. 2012;51(16-18):3417-27.

59. Palacin L, de Prada C, Tadeo F, Salazar J. Operation of mediumsize reverse osmosis plants with optimal energy consumption. Proceedings of the 9th International Symposium on Dynamics and Control of Process Systems (DYCOPS 2010). 2010. 